\title{
УКРАЇНСЬКА МУЗИЧНО-ТЕАТРАЛЬНА КУЛЬТУРА ДРУГОЇ ПОЛОВИНИ ХІХ - ПОЧАТКУ ХХ СТ. В АСПЕКТІ ОПЕРНОЇ ТВОРЧОСТІ С. МОНЮШКА
}

\section{Федотова О. O.}

\section{ВСТУП}

Характерною ознакою розвитку культури будь-якого народу $\epsilon$ процес акультурації, який передбачає комунікативну взаємодію та культурний взаємовплив. Українська культура в ході своєї еволюції збагатилася елементами різноманітних культурних традицій. Зокрема, суттєвим можна вважати вплив європейських тенденцій на розвиток українського музично-театрального мистецтва II половини XIX початку XX ст. Прикладом того може бути творчість знаного польского композитора Станіслава Монюшка, котрий по праву визнаний фундатором польської табілоруської опер, серед яких «Галька», «Зачарований замок» («Страшний двір»), «Парія», «Ідилія» тощо. На основі музичних здобутків Ю. Ельснера та К. Курпінського діяч написав реалістичні за своїм характером національні твори, особливістю яких стало їхне демократичне спрямування. Із понад 15 опер, що формують мистецький доробок С. Монюшка, високою художністю позначені насамперед твори «Галька» та «Зачарований замок» («Страшний двір»). Остання п’єса також вважається зразком музично-театрального мистецтва та стала не менш популярною, ніж опера «Галька».

Будучи досить різнобічною особистістю, композитор звертався до різних музичних жанрів. Творчі напрацювання автора репрезентовані також балетами, опереттами, водевілями, кантатами, оркестровими п’єсами, струнними квартетами, месами тощо. Йому належить близько 400 пісенних композицій, котрі досліджені далеко не повністю. Саме пісні С. Монюшка стали підгрунтям для подальшого розвитку польської вокальної музики. Із приводу походження польської пісні М. Томашевський серед іiі основних властивостей наголошував на спорідненості історичних зв'язків у межах цілісної єдності литовських, білоруських і українських земель у складі Польського королівства, 
оскільки їхній фольклор розвивався рівноправно ${ }^{1}$. Зокрема, С. Монюшко у процесі творчої діяльності часто поєднував музичні композиції з литовськими, білоруськими, українськими текстовими матеріалами, тож його твори мали яскраво народне фольклорне звучання. Оперна спадщина композитора також увібрала в себе характерні елементи селянського фольклору слов'янських народів. Щирість, відвертість почуттів, лірична теплота та мелодійність творів автора не могли не звернути на себе увагу як відомих українських виконавців, так і театральних режисерів.

Спробуємо з'ясувати важливість оперного доробку С. Монюшка як фактору становлення української музично-театральної культури вказаного періоду.

\section{1. Вплив оперної спадщини С. Монюшка на розвиток українського музично-театрального мистецтва II половини XIX ст.}

Майбутній композитор побачив світ у невеличкому селі Убель у Білорусі у родині збіднілої шляхти. На становлення музичних смаків хлопця великий вплив мала матір, яка змогла закласти в нього інтерес і любов до народного мистецтва. Це, у свою чергу, сприяло формуванню морально-естетичних ідеалів і національних почуттів особистості. Дитинство Станіслава пройшло як у Мінську, так і у Варшаві, де він, будучи гімназистом, брав уроки з теорії музики.

У 1837-1840 рр. юнак навчався у Співочій академії Берліна, опановуючи прийоми роботи 3 хором та оркестром, а також знайомлячись із загальними тенденціями розвитку європейських культурних традицій. 1838 р. побачили світ «Три пісні» на слова А. Міцкевича. Наступного року із музикою С. Монюшка у Львові була здійснена постановка п’єси А. Фредра «Ночівля в Апеннінах».

Здобувши освіту, діяч повернувся до Вільна, де протягом 18401858 рр. працював на посадах церковного органіста, вчителя музики, диригента, імпресаріо тощо. Тоді з'явилися перші оперні твори автора («Деал», «Лотерея»). 1947 р. композитор завершив оперу «Галька», після чого, головним чином, займався пісенною творчістю та написанням романсів. Результатом того стала поява 1848 р. збірника під назвою «Домашній пісенник», одного із 12 видань, що стали

Бернацька-Гловаля Е. Польська пісня у Львові (соціоісторичний та культурологічний аспект). Наукові збірки Львівської національної музичної академії ім. М.В. Лисенка. 2013. Вип. 29. С. 151-166. URL: http://nbuv.gov.ua/UJRN/ Nzlnma_2013_29_1. 
широко популярними завдяки їхньому народному характеру та заклали підгрунтя для подальшого розвитку польської вокальної музики ${ }^{2}$.

Надалі, після успішної постановки опери «Галька», митець був запрошений на посаду диригента Варшавської опери та посів місце професора Музичного інституту. На тому етапі композитор написав низку комічних опер «Сплавщик лісу», «Графиня», «Слово честі».

Знаменною подією у музичному житті стала прем'єра 1865 р. опери «Страшний двір» («Зачарований замок»), яка, однак, через іiі патріотичне звучання після декількох вистав була заборонена царською цензурою $^{3}$. Цей мелодійний твір суттєво вирізнявся багатством сценічного матеріалу та динамічністю постановки. Передання за допомогою різноманіття музичних засобів неповторного колориту старовинного маєтку на підставі романтично-гротескного сюжету заклало основу для формування нової течії у польському музичному мистецтві. На тогочасних глядачів величезне враження справляв показ польського воєнного табору і лицарів на початку п'єси ${ }^{4}$.

Того ж року творчу скарбницю композитора поповнила й кантата «Привиди». На жаль, написані ним твори (опери «Парій», «Беата») не були широко визнані. Композитор пішов із життя 4 червня 1872 р.

Найбільш яскраво творчі погляди С. Монюшка відбилися в опері «Галька», де автор розкрив повну драматизму долю дівчини з народу, введену в оману багатим шляхтичем. Сюжет твору був вибудуваний його приятелем, В. Вольським на основі новели К. Вуйціцького «Горянка».

Мотивом, що надихнув діяча на створення опери, стало посилення революційного руху серед польського селянства, який активізувався у 1840-х рр. Згідно із творчим задумом автора у фіналі твору мало бути зображене селянське повстання як протест проти соціальної несправедливості. Враховуючи тогочасні цензурні вимоги, п’єсу довелося суттєво видозмінити та «пом'якшити», але навіть після значної переробки вона зберегла соціальне спрямування.

В основу сюжетної лінії С. Монюшко поклав життєву історію про долю дівчини-сироти 3 народу - селянки Гальки, котра покохала молодого панича Януша, а той, у свою чергу, зрадив їі. Коли у дівчини народилася дитина, шляхтич кинув їх напризволяще. Простий парубок Йонтек, усією своєю душею щиро відданий Гальці, піклуючись про молоду матір і немовля, намагався розкрити їй очі на справжню

${ }^{2}$ Калениченко А. Монюшко Станіслав. Українська музична енциклопедія. Київ : IMФЕ, 2011. Т. 3. C. 482-483.

3 Там само.

${ }^{4}$ Самин Д. 100 великих композиторов. Москва : Вече, 2014. 432 с. 
сутність пана. Нарешті парубкові вдається переконати дівчину у непорядності та підступності панича. Шляхтич жорстоко поводиться 3 Галькою, вигнавши іiі зі свого маєтку. Прозріння щодо справжнього ставлення до неї Януша стає важким ударом для дівчини, внаслідок чого вона божеволіє. Засліплена бажанням помститися, Галька намагається підпалити костел, де відбувається вінчання Януша 3 рівною йому за соціальним походженням партією - дочкою стольника, проте збагнувши, що у пожежі можуть загинути ні в чому не винні селяни, присутні на весіллі, вона відмовляється від своїх початкових намірів. Перебуваючи у стані глибокого розпачу, відчаю та безпорадності, дівчина вирішує закінчити життя самогубством i кидається у ріку. Останньою сценою стає туга простого народу біля костелу за скривдженою паничем Галькою, яку не встигли врятувати.

Характерним $\epsilon$ те, що, незважаючи на відсутність в опері польських національних пісень, вона сприймається як глибоко народний твір. Образи головних героїв окреслені достатньо чітко завдяки використаним музичним засобам (арія й пісенні партії Гальки, думка Йонтека). Повнотою живих емоцій сповнений спів селянського хору. Відчувається, що автор орієнтується саме на традиції народної пісенності, із симпатією ставлячись до простого люду. На відміну від цього, музичний супровід під час зображення аристократії позначений холодністю задля передання пихатості й егоїзму панівної верстви. 3 урахуванням вказаних тенденцій навіть абсолютно протилежно в опері звучать дві мазурки. Так, твір, що грають у маєтку стольника, характеризується офіційно-бравурною інтонацією і має ознаки бальної композиції, а мазурка, виконувана хором селян із третього дійства п’єси, сприймається як щиро народна ${ }^{5}$.

Прем'єра п'єси відбулася на віленській сцені 1848 р. Слід зазначити, що їі постановка супроводжувалася значними труднощами. Від самого початку аристократія не вітала факт постановки опери, де явно переважали симпатії до народу, а шляхта була показана у досить невигідному світлі. Автор вимушений був вкласти чимало власних коштів в оформлення вистави, знайти виконавця головної ролі Йонтека через відсутність співака-тенора. Діяч переробив арію головного героя на баритонову, а також вирішив запросити італійського оперного артиста ${ }^{6}$. Решту партій виконали аматори-любителі. Незважаючи на усі згадані перешкоди, п'єса мала успіх.

5 Там само.

6 Горський Г. Про оперу «Галька». URL: https://zbruc.eu/node/45366 (дата звернення: 22.01.2021). 
Професійна постановка опери була здійснена у Варшаві 1858 р. Аналогічно попередній, вона також вийшла із певними складнощами. Так, композиторові заборонили ставити двохактову оперу, аргументуючи тим, що тогочасний глядач традиційно звик і більш прихильно сприймав чотирьохактові спектаклі, поєднані з балетними сценами, яких бракувало твору С. Монюшка. Під тиском означених вимог композитор вимушений був вдатися до кардинальної переробки опери, умовно розподіливши матеріал у межах чотирьох основних дій. Автор дописав також фінальну сцену другого акту, антракт, низку арій діючих осіб. Епізоди 3 політичним підтекстом С. Монюшку довелося зняти. Син композитора згадував: «Батько плакав ночами від гострого болю, що під тиском обставин довелося так понівечити свій твір»7. Хоча соціальна проблематика п'єси внаслідок цих змін і втратила частково свою гостроту, тим не менш, саме відтоді опера стала справжнім шедевром світового репертуару, здобувши широкий розголос і популярність.

За запрошенням Галицького музичного товариства $1865 \mathrm{p}$. С. Монюшко, як його почесний член, відвідав Львів. Композитор був присутній у Міському театрі на прем'єрі «музичної картини ліричних сцен», кантати «Привиди». Останній твір під диригуванням автора на концертах 22, 26 лютого і 3 березня успішно виконали театральний колектив і хор, солісти й оркестр товариства ${ }^{8}$.

Пізніше, у 80-х pp. XIX ст. у програмах камерних концертів-ранків і вечорів Галицького музичного товариства знаходимо заявлені твори С. Монюшка, зокрема арію $з$ опери «Графиня» (4 квітня 1883 р.). На день Конституції в концертній залі «Сокола» у виконанні жіночого хору вказаної організації разом з іншими патріотичними творами прозвучав також полонез із опери «Галька». До програми великого концерту, приуроченого до відкриття концертної зали у Стрийському парку, влаштованого комітетом музичної секції Загальної крайової виставки 8 червня 1894 р., увійшли «Жовнірська пісня» та «Рицарська пісня» композитора в обробці Я. Галля. У свою чергу, концертна програма, запланована товариством на 25 червня 1894 р., також містила такі твори С. Монюшка, як «Дует 3 опери "Парія" для тенора i баритона 3 оркестром» (перше виконання), Концертний полонез для оркестру (перше виконання) та баладу «Повернення батька» в опрацюванні П. Машинського. Хором «Лютні» 31894 по 1907 рр. самостійно та за участі колективів Галицького музичного товариства були виконані такі

${ }^{7}$ Там само.

${ }^{8}$ Мазепа Т.Л. Галицьке Музичне Товариство у культурно-мистецькому процесі XIX - початку XX століття : дис. ... докт. мистецтвознавства : 26.00.01; Національна академія керівних кадрів культури і мистецтв, Міністерство культури України. Київ, 2018. C. 187-188. 
кантатно-ораторійні твори композитора, як: балада «Пані Твардовська», «Кримські сонети», «Реквієм», «Остробрамська літанія» ${ }^{9}$.

1867 p. ознаменувався відкриттям в Україні першого оперного театру під керівництвом артиста та режиссера I. Сетова, котрому вдалося підібрати блискучий акторський склад трупи. До репертуару вказаного закладу також увійшла і п'єса «Галька» С. Монюшка. Видатний російський композитор і диригент П. Чайковський після перегляду опери відзначав чудові результати звучання хорового колективу, спів якого, завдяки докладеним зусиллям керівника та диригента I. Альтані, а також злагодженій співпраці помічника, піаніста А. Геккеля, характеризувався бездоганним рівнем виконання ${ }^{10}$. У 1873 р. на сцені Київської опери російською мовою вперше була зіграна п'єса «Страшний двір».

На початку 1880-х pp. на фоні певного послаблення тиску російського царату щодо української культури знані вітчизняні діячі М. Кропивницький і М. Старицький активізували роботу з організації національного за своїм характером музично-драматичного театру. Внаслідок того восени 1882 р. вже була сформована трупа М. Кропивницького, котра дебютувала 3 «Наталкою Полтавкою» I. Котляревського. Тією ж оперою наступного року відкрив свою творчу діяльність і театральний колектив під керівництвом $\mathrm{M}$. Старицького, після чого невдовзі відбулося об'єднання двох музичнодраматичних труп. Засновникам вдалося створити високопрофесійний колектив акторів, які блискуче грали і в драматичних п'єсах, і в оперноопереткових виставах. У 1885 р. останній розпався на два автономні.

Слід зазначити, що в репертуарному списку драматичної трупи Старицького превалювали музичні твори. Діяч здійснив спробу суттєво розширити оперний репертуар, включивши до нього зарубіжні й російські п'єси в українських перекладах. Зокрема, 1887 р. митець мав наміри поставити оперу «Галька» С. Монюшка, переклавши лібрето до неї українською мовою, у зв'язку з чим надав до Головного управління у справах друку запит, супроводжуваний вже готовим рукописом, задля отримання дозволу, однак за півроку бюрократичного очікування наштовхнувся на цензурну заборону його інсценізації ${ }^{11}$.

${ }^{9}$ Там само.

10 Чайковский П.И. Киевская опера. Четвертое симфоническое собрание. Музыкально-критические статьи. Ленинград : Музыка, 1986. 365 с.

${ }_{11}$ Станішевський Ю. Український театр кінця ХІХ - початку ХХ століть: Проблеми синтетичної природи i становлення національного режисерського мистецтва. Нариси з історії театрального мистецтва Украӥни ХX століття / Інститут проблем сучасного мистецтва Академії мистецтв України ; редкол. : В. Сидоренко та ін. Київ : Інтертехнологія, 2006. С. 14. 
Знаний український оперний співак О. Мишуга восени 1880 p. розпочав свою кар'єру у Львівському міському театрі, беручи участь у постановці фрагментів 3 опери Монюшка «Зачарований замок» («Страшний двір»). Невдовзі після дебюту та яскравих виступів в Італії його запросили працювати до театру Скарбека. В оперному сезоні $1883-$ 1884 pp. О. Мишуга виконав низку головних партій, у т. ч. і Йонтека 3 «Гальки». Загалом співак більш як 600 разів виступав у цій ролі, блискуче передаючи образ і переживання парубка. 1884 р. артист вирушає у гастрольну поїздку до Варшави, де одразу ж після першого виступу у Великому Варшавському театрі йому пропонують підписати контракт, що знаменує початок його сценічної кар'єри. Артист дедалі більше опановує європейський оперний репертуар. Особливо варто відзначити аншлагову реакцію глядацької аудиторії після виконання ним арії «Шумлять сосни» 3 опери Монюшка, під час якої панувала повна тиша, зал завмирав, а потім наповнювався шквалом оплесків і викликами актора «на біс» ${ }^{12}$. Така проникливість звучання частково пояснювалася схожістю пережитої співаком особистої трагедії з долею головного героя, оскільки він дуже важко переніс втрату коханої, актриси М. Вісньовської, вбитої 1890 р. офіцером царської армії. О. Мишугу захоплено зустрічала як варшавська, віденська, санкт-петербурзька, римська, берлінська, празька, так і львівська, київська публіка. Партнерами співака на сцені під час закриття оперного сезону в театрі Скарбека 16 жовтня 1894 р. були знані співаки С. Крушельницька та Г. Гурський. У наступному сезоні О. Мишуга успішно виступив в опері С. Монюшка «Зачарований замок» («Страшний двір»).

У Варшавській опері також неперевершено грала українська оперна діва С. Крушельницька, котра дебютувала у ролі Аїди з однойменного твору Дж. Верді. Надалі вона виконала цілу низку відомих оперних партій, зокрема співаючи у п’єсах «Галька» та «Графиня» С. Монюшка. Тогочасні критики високо оцінювали виступи С. Крушельницької, підкреслюючи, що артистка вдало поєднувала засоби вокальної майстерності із драматизмом акторського виконання та тонким психологізмом. Усього майже за неповних п'ять років роботи у театрі виконавиця досягла мистецьких вершин. Особливо іiі приваблював образ Гальки, за рівнем передання «щирості та правдивості почуттів» якої зі співачкою ніхто не міг конкурувати ${ }^{13}$.

12 Видатний співак Олександр Мишуга: спогади / зібрав I. Деркач. Львів : Каменяр, 1964. 119 с.

13 «Halka». Opera Stanisława Moniuszki. 100 lat na scenie. 1858-1958 / Materiały zebrał i oprac. J. Grubowski. Warszawa : Państwowa opera w Warszawie, 1958. S. 15. 
На свій бенефіс 14 березня 1899 р. С. Крушельницька блискуче виконала на сцені улюблену партію. У переповненому театрі артистка настільки правдиво розкрила персонаж Гальки, що кожне іiі слово дозволило глядачам глибоко відчути й емоційно пережити трагедію головної героїні. На підставі того польська музична критика назвала приму «незрівняною постаттю в оперному мистецтві» ${ }^{14}$.

У зв'язку з п'ятисотою постановкою твору 9 грудня 1900 р. співачка запросила на п'єсу за іiі участю та замовила театральну ложу для першої виконавиці ролі Гальки, В. Ростковської, затвердженої свого часу на прем'єру самим С. Монюшком ${ }^{15}$. Необхідно зазначити, що похилого віку актриса перебувала тоді у притулку Св. Францішка Салезі, зазнаючи значної матеріальної скрути. Відповідно до запланованого заходу журналістами у періодиці була ініційована доброчинна акція, покликана поліпшити фінансове становище жінки, яку активно підтримала саме С. Крушельницька. Співачка матеріально допомогла В. Ростковській, а після завершення ювілейної вистави урочисто вручила букет квітів.

Слід навести один із відгуків на виступ актриси польської критики: «Щоб підкреслити свої артистичні якості, п. Крушельницька не могла вибрати кращої партії ніж Галька. <..> Завдяки силі таланту п. Крушельницької образ сільської дівчини вийшов в ідеальному віянні, сповнений природного чару, щирості почуттів і вражаючий у грі життєвою правдою. Чудовий голос артистки надається до цієї партії так, як цього вимагає витончене та шляхетне мистецтво; у голосі $€$ легке тремолювання, але тут воно лише поглиблює вираження почуттів, забарвлює спів сильнішим душевним хвилюванням» ${ }^{16}$. Спектакль мав великий резонанс, оскільки його розглядали як своєрідний ланцюг між двома століттями, що сприяв наданню національній опері світового визнання.

Ще одним безперечним успіхом на сцені Варшавської опери став виступ актриси 1900 р у п'єсі С. Монюшка «Графиня». Лібрето, яке виконувала С. Крушельницька, мало сатиричне забарвлення. У ньому в жартівливій формі розкривалися різні аспекти легковажного i безтурботного існування аристократичних кіл. Протилежно тому висвітлювалися принципи життя простого народу на основі збереження традиційної пісенної культури, мови, звичаїв та обрядів.

${ }^{14}$ Врублевська В. Соломія Крушельницька : роман-біографія. Київ : Дніпро, 1986. 358 c. URL: https://litgazeta.com.ua/chytaty-onlayn/vrublevska-valeria-vasilivnasolomia-krushelnicka/.

${ }^{15}$ Kański J. Mistrzowie sceny operowej. Kraków : PWM, 1974. S. 26.

${ }^{16}$ Stattler Ju. Z opery. Stowo (Варшава). 1898. № 230. S. 9. 
Артистка вміла майстерно перевтілюватися. Так, у першому акті вистави вона демонструвала публіці образ легковажної молодої вдови як представниці богеми, котра живе модними розвагами та фліртує 3 чоловіками. Графиня нібито звертала увагу на залицяння Казиміра, але водночас всією своєю поведінкою підкреслювала відсутність у кавалера світських манер.

А. Сигетинський, аналізуючи виступ актриси у згаданій виставі, констатував, що, заглибившись у духовний світ графині, їй «вдалося створити шедевр психологічної музики» ${ }^{17}$. Неповторний мистецький талант дозволив С. Крушельницькій передати усі тонкощі емоцій i відтінки почуттів.

\section{2. Розвиток української музично-театральної культури початку XX ст. крізь призму оперного доробку С. Монюшка}

На початку XXI ст. українське мистецтво активно еволюціонувало під впливом європейських i вітчизняних театральних здобутків. Знаменною подією музично-театрального життя стала організація у Києві 1907 р. першого стаціонарного професійного театру «Трупа українських артистів під керівництвом Миколи Садовського». Режисер основним завданням окреслив створення трупи, яку б можна було повністю задіяти для постановки великих вистав. Митець запросив до театрального колективу як уже відомих метрів, так і молодих акторів, зокрема В. Верховинця, котрий переїхав до Києва 3 Галичини. Видатний режисер був вражений приємним голосом (лірикодраматичним тенором) юнака, природною артистичністю та хормейстерськими здібностями ${ }^{18}$. Саме В. Верховинцю належала ініціатива перекласти у 1909-1910 pp. українською мовою та здійснити постановку відомих опер Масканьї «Сільська честь» і Монюшка «Галька» ${ }^{19}$. Творчі ідеї молодого артиста дозволили значно розширити напрями роботи закладу й успішно реалізувати нові оперні постановки. Зокрема, В. Верховинець ретельно опрацював оркестрові партитури оперних творів і здійснив їх переклад для малого симфонічного оркестру, тим самим адаптувавши для музично-драматичного театру. У першому театральному сезоні юнак майстерно виконав роль Йонтека 3 опери С. Монюшка «Галька», з якою раніше протягом 1904-1906 pp.

17 Врублевська В. Соломія Крушельницька : роман-біографія. Київ : Дніпро, 1986. 358 c. URL: https://litgazeta.com.ua/chytaty-onlayn/vrublevska-valeria-vasilivnasolomia-krushelnicka/.

${ }_{18}^{18}$ Садовський М.К. Мої театральні згадки: 1881-1917 pp. Харків, 1930. С. 90-91.

19 Васильченко Т. Верховинець (Костів) Василь Миколайович. Реабілітовані історією. Полтавська область. Кн. 5 / упоряд. О.А. Білоусько. Київ - Полтава : Оріяна, 2007. С. 56. 
як актор-співак виступав у складі трупи Руського народного театру при Львівському товаристві «Руська бесіда» ${ }^{20}$.

Величезна увага у театрі М. Садовського приділялася саме музичній складовій частині. Окрім оперних творів («Запорожець за Дунаєм», «Продана наречена», «Галька», «Катерина»), до репертуару входили також вистави, що характеризувалися змішаним жанром, скажімо, музично-драматичні, де суттєвий акцент робився на пісенних i танцювальних композиціях. Прикладом таких робіт може бути «Енеїда» I. Котляревського, підготовлена режисером для театральної постановки. У театрі на постійній основі діяв висококласний оркестр. 3 огляду на професійний підхід до відпрацювання музичного матеріалу знані тогочасні композитори (К. Стеценко, М. Лисенко та ін.) за власною ініціативою пропонували митцю нові твори.

Невдовзі оперна режисура засновника звернулася на себе увагу критиків. Значним досягненням стало створення народного театру, де грали реалістичні п’єси, а також ставили глибоко соціальні вистави. Це, безперечно, свідчило про новаторський підхід до музичної режисури. За умов систематичних утисків української культури російським царизмом М. Садовському вдалося на невеличкій камерній сцені запропонувати глядачеві оперні твори, дія яких супроводжувалася бездоганним оркестровим виконанням i чудовим вокальним співом. До таких постановок можна віднести спектаклі «Наталка Полтавка» I. Котляревського, «Сільська честь» П. Масканьї, «Продана наречена» Б. Сметани тощо. У репертуарі театру фігурувала також і вистава «Галька» С. Монюшка, яку тоді також досить активно ставила київська опера.

М. Садовський у процесі власної творчості здійснив спробу зробити оперу більш доступною для масового глядача за рахунок реалістичного показу життєвих сцен, урахування етнографічних елементів.

Базові засади режисерського бачення найбільш повно розкрилися якраз у ході постановки вказаного вище твору. Незважаючи на те, що виставі були притаманні поєднання драматичного виконання із ретельно продуманим музичним супроводом, вокального співу із художньо-образним структуруванням сценічного дійства, все ж таки у ній мала місце певна невідповідність образного змісту музики засобам iii сценічного донесення. Необхідно зазначити, що М. Садовський здійснив переклад опери «Галька» українською мовою та за власною ініціативою інтерпретував твір відповідно до українського контексту, екстраполюючи події в карпатський регіон і змінивши польських селян на гуцулів, для чого закцентував увагу на відповідних етнографічних

20 Дем'янко Н.Ю. Формування національної культури молоді в педагогічній спадщині В.М. Верховинця. Полтава : АСМІ, 2012. 270 с. 
і побутових деталях, посилених масовими епізодами. В. Верховинець, талант якого як хореографа розкрився саме у цьому театрі, 3 урахуванням фольклорних особливостей поставив досі невідомий широкій публіці західноукраїнський народний танець «Аркан», який згодом критики назвали «блискучим» ${ }^{21}$. Завдяки поєднанню усього комплексу засобів як сама драма, так і музичний супровід виглядали доволі реалістично. Тому сприяли і величні декорації карпатських гір, справжні гуцульські костюми артистів, а також продумані до дрібниць предмети побуту, що підкреслювали етнічну неповторність регіону, у якому розгорталися події.

У сезоні 1909-1910 рр. відбулася прем’єра згаданої п’єси, де партію Гальки блискуче виконала О. Петляш, Йонтека - С. Бутовський, Стольника - Д. Бутовський, Януша - П. Рязанець. Вихована на спеціальних мовно-вокальних прийомах фонетичної методики, розробленої О. Муравйовою (педагогом-репетитором театру М. Садовського), О. Петляш повною мірою розкрила на сцені свій вокально-драматичний талант ${ }^{22}$.

За оцінками деяких місцевих театральних критиків, чию думку можна вважати неоднозначною, М. Садовському вдалося спростити п’єсу, «наблизившись у своєму стилі до національного джерела» ${ }^{23}$. Постановка відрізнялася чітко вираженою соціальною проблематикою, психологізмом, гостротою конфлікту, робила твір доступнішим для масової аудиторії, однак надання опері українізованого характеру суперечило творчому задуму С. Монюшка, а також порушувало оригінальне музичне звучання твору.

Водночас застосування режисером низки новаторських прийомів дозволило говорити про цілісність усіх складових елементів дійства, чітку відпрацьованість навіть найдрібніших епізодів. К. Стеценко, порівнюючи першу сцену четвертого акту у постановці М. Садовського 3 аналогічною у міському театрі, підкреслював іiі емоційно живий характер, смислову продуманість кожної репліки, залученість

${ }^{21}$ Васильченко Т. Верховинець (Костів) Василь Миколайович. Реабілітовані історією. Полтавська область. Кн. 5 / упоряд. О.А. Білоусько. Київ - Полтава : Оріяна, 2007. С. 56-60.

${ }_{22}$ Антонюк В. Олена Олександрівна Муравйова - професор вищої школи імені М.В. Лисенка. Микола Лисенко: історія $і$ сучасність : Збірник наукових праць. До 175-ої річниці від дня народження композитора / упоряд. Р. Скорульська, О. Гураль, ред. І. Чиркова. Київ, 2019. С. 4-23.

23 Станішевський Ю. Український театр кінця XIX - початку XX століть: Проблеми синтетичної природи $\mathrm{i}$ становлення національного режисерського мистецтва. Нариси з історії театрального мистецтва Украӥни XX століття / Інститут проблем сучасного мистецтва Академії мистецтв України ; редкол. : В. Сидоренко та ін. Київ : Інтертехнологія, 2006. С. 48. 
учасників масових сцен до особистої трагедії головної героїні через показ співпереживання та доповнення акторами ходу дії. Згадана сцена у київській опері, на відміну від попередньої, виглядала доволі шаблонно, сіро та не цікаво ${ }^{24}$.

Як наслідок, постановка опери режисером відрізнялася національним контекстом, соціальним забарвленням, психологічною спрямованістю, певною ліричною опоетизованістю від однойменної вистави міського театру, де основний акцент робився на особистій трагедії героїні твору, яку відштовхнув від себе шляхтич. Режисерський задум М. Садовського дозволив піднести історію героїні твору до рівня гострої соціальної проблематики. На соціальному звучанні твору в аспекті його більш розширеного трактування наголосив Ю. Станішевський: «Польський пан Януш (П. Рязанець) безжалісно насміявся з бідної селянки Гальки (О. Петляш), довівши іiі до самогубства. Якщо в міському театрі фінальна сцена вистави, коли Галька у відчаї кидалася в бурхливу річку, а безпорадні чепурні селяни сумно схилялися над героїнею, яку виносив із-за куліс і клав у центрі сцени Йонтек, звучала жалісно й безнадійно, то у спектаклі М. Садовського фінал сприймався як гнівний народний протест проти панської сваволі та жорстокості. Йонтек, піднявши на руки тіло коханої, виходив на крутий берег і неначе прямував до костелу, де вінчалися зрадливий Януш і Софія. Його обступали гуцули, що рвучко підносили вгору топірці. Грізною, незборимою хвилею вони насувалися на панів, котрі якраз виходили 3 костелу. Таким режисерським акордом завершувався цей спектакль» ${ }^{25}$.

У 1911 p. 3 партією Стольника у «Гальці» дебютував відомий український співак $\mathrm{T}$. Івлєв, який виступав під псевдонімом Трохименко. Артист мав сильний голос-бас із досить широким діапазоном звучання й особливим тембром. 1912 р. 3 партією Йонтека вперше на сцені театру М. Садовського виступив вихованець знаного українського співака Філіппі-Мишуги, тенор М. Микиша, про дебют якого схвально відгукувалися театральні критики. Як зазначав артист, основний акцент режисером робився не на вокальному звучанні, як у більшості тогочасних місцевих приватних антрепризних театрів, а на органічному створенні вокально-сценічного образу героя, правдивому

24 Станішевський Ю. Український театр кінця XIX - початку XX століть: Проблеми синтетичної природи i становлення національного режисерського мистецтва. Нариси з історії театрального мистецтва України XX століття / Інститут проблем сучасного мистецтва Академії мистецтв України ; редкол. : В. Сидоренко та ін. Київ : Інтертехнологія, 2006. С. 49.

${ }^{25}$ Там само. С. 50. 
показі та всебічному розкритті рис характеру персонажів твору ${ }^{26}$. Того ж року М. Садовський запросив на посаду диригента театру О. Кошиця, котрий працював у складі його колективу до 1916 р. Заглибившись у роботу, відомий композитор успішно поновив опери «Галька» С. Монюшка й «Енеїду» М. Лисенка.

Принципи музичної режисури М. Садовського суттєво вплинули на методику сценічної постановки опер та оперет у мандрівних українських трупах О. Суслова, Д. Гайдамаки, О. Суходольського, Л. Сабініна, І. Сагатовського. Так, наприклад, режисером, актором й антрепренером О. Сусловим доволі успішно ставилися оперні твори С. Монюшка. Протягом 1898-1909 рр. арію Гальки з однойменної опери композитора у складі його колективу виконувала відома актриса $€$. Зарницька. Під час гастролей у Москві вона прославилася як одна 3 перших вітчизняних артисток, котра опанувала західноєвропейський оперний репертуар. Критики схвально писали про яскравий драматичний талант співачки, поєднаний із чарівністю вокальних даних, а також відзначали рідкісне вміння органічно вжитися у будьяку роль. Не менш яскравими були постановки творів Монюшка трупою Д. Гайдамаки, де драматичний репертуар вдало поєднувався 3 музично-драматичним і оперетково-оперним.

Вигідно вирізнялися майстерністю також вистави, реалізовані у 1908 1912 рр. Й. Стадником на сцені західноукраїнського театру товариства «Руська бесіда». Не випадково опери, зіграні трупою, критика оцінювала значно вище порівняно зі спектаклями польського театру у Львові та німецького у Чернівця ${ }^{27}$. Й. Стадник також суттєво розширив репертуар колективу такими операми, як «Запорожець за Дунаєм» ГулакаАртемовського, «Сільська честь» Масканьї, «Фауст» Гуно, «Свгеній Онегін» Чайковського, «Різдвяна ніч» Лисенка, «Мадам Батерфляй» Пучіні, «Казки Гофмана», «Травіата» Верді тощо. Показовим є те, що більшість із названих творів вперше було виконано українською мовою. На сцені театру успішно йшла й опера «Галька» С. Монюшка.

За доби Гетьманату П. Скоропадського в Україні провадилася величезна робота із започаткування національної опери та здійснювалася підготовка до відкриття нового театрального сезону.

26 Станішевський Ю. Український театр кінця XIX - початку XX століть: Проблеми синтетичної природи $\mathrm{i}$ становлення національного режисерського мистецтва. Нариси з історії театрального мистецтва України XX століття / Інститут проблем сучасного мистецтва Академії мистецтв України ; редкол. : В. Сидоренко та ін. Київ : Інтертехнологія, 2006. С. 51.

27 Український драматичний театр: нариси історії : в 2 т. Т. 1. Дожовтневий період / АН УРСР, Ін-т мистецтвознавства, фольклору та етнографії ім. М.Т. Рильського ; відп. ред. М.Т. Рильський. Київ : Наук. думка, 1967. С. 425. 
Видатними українськими письменниками Л. СтарицькоюЧерняхівською, О. Олесем, С. Черкасенком влітку 1918 р. були перекладені українською мовою оперні лібрето із п'єс «Галька», «Казки Гофмана», «Мадам Батерфляй», «Травіата» тощо ${ }^{28}$.

1919 р., тимчасово обіймаючи посаду очільника Державної української музичної драми, оперу «Галька» С. Монюшка разом із творами М. Лисенка «Утоплена» та «Тарас Бульба» підготував до постановки знаний український режисер Л. Курбас, проте призначеній на 30 серпня прем'єрі «Гальки» не судилося відбутися у зв'язку зі вступом військ Денікіна до Києва ${ }^{29}$.

\section{ВИСНОВКИ}

Таким чином, за результатами дослідження можна зробити висновок, що оперна спадщина Станіслава Монюшка суттєво вплинула на розвиток української музично-театральної культури II половини $\mathrm{XIX}$ - початку XX ст. Вітчизняні актори успішно брали участь У театральних постановках оперних творів композитора як на українській, так і на європейській сцені. Найбільш популярними стали опери «Галька», «Зачарований замок» («Страшний двір») i «Графиня». Виконання партій головних героїв 3 означених творів сприяло у II половині XIX ст. всебічному розкриттю талантів таких відомих виконавців, як С. Крушельницька й О. Мишуга. Виступи акторів на сцені Варшавської опери та театру Скарбека здобули високу оцінку театральної критики. Співак протягом своєї музично-театральної діяльності більш як 600 разів виступив у ролі Йонтека.

Творча спадщина С. Монюшка активно вплинула і на формування музичного репертуару колективів, що діяли на західноукраїнських землях. Так, твори композитора активно виконувалися під час камерних концертів-ранків i вечорів, влаштованих Галицьким музичним товариством, на сцені концертної зали Сокола тощо.

П'єси «Галька» та «Страшний двір» також успішно йшли на сцені київської опери.

Здійснити постановку «Гальки» 3 перекладом лібрето українською мовою 1887 р. намагався М. Старицький, однак наштовхнувся на заборону рукопису п'єси органами царської цензури.

${ }^{28}$ Гай-Нижник П. Становлення українського театрального мистецтва і питання його оподаткування за Гетьманату 1918 року. Украӥнський театр. 2003. № 5-6. C. 10-12.

29 Леоненко Я., Фількевич Г. Музичний простір вистав Леся Курбаса. Нариси з історї театрального мистецтва Украӥни XX століття / Інститут проблем сучасного мистецтва Академії мистецтв України; редкол. : В. Сидоренко та ін. Київ : Інтертехнологія, 2006. С. 349. 
На початку XX ст. опери С. Монюшка поповнили репертуар новоствореного у Києві першого стаціонарного професійного театру «Трупа українських артистів під керівництвом Миколи Садовського». Сміливою спробою постановки п’єси «Галька» в україномовному варіанті стала українізована версія твору, запропонована М. Садовським. Новаторські прийоми сценічної режисури, передання народного характеру опери й етнографічного колориту дійства, вокально-драматичний талант виконавців були високо оцінені критикою, проте вільна інтерпретація сюжету призвела до часткової невідповідності образно-музичного звучання засобам сценічної постановки. Це спричинило деяке порушення авторської партитури.

Загалом за період діяльності театру участь у постановці п'єс С. Монюшка брали такі відомі виконавці, як В. Верховинець, О. Петляш, М. Микиша, Т. Івлєв та ін. Про зацікавленість українських діячів культури оперною спадщиною діяча свідчить інтерес знаного музиканта та хорового диригента О. Кошиця, якому належить досвід поновлення «Гальки» під час роботи у театральному колективі М. Садовського.

Як бачимо, у репертуарі пересувних українських труп (О. Суслова, Д. Гайдамаки та ін.) теж фігурувала опера «Галька» С. Монюшка. Твір неодноразово ставився i режисером Й. Стадником у західноукраїнському театрі товариства «Руська бесіда».

Особливу увагу до твору «Галька» можемо спостерігати на різних етапах розвитку української музично-театральної культури, що виявилося у намаганнях низки діячів перекласти українською й поставити п'єсу за умов Російської імперії, а також у здійсненні перекладу лібрето із п’єси за часів Гетьманату, намаганні Л. Курбаса поставити спектакль у Державній українській музичній драмі 1919 р.

Таким чином, можна констатувати, що оперні твори С. Монюшка успішно увійшли до репертуару як пересувних українських труп, так і театрів, які функціонували на українських землях у II половині XIX на початку XX ст. Виконання ролей $з$ опер видатного композитора сприяло становленню цілої плеяди знаних українських співаків і драматичних акторів.

\section{АНОТАЦІЯ}

У статті розкрито вплив оперної спадщини видатного польського композитора С. Монюшка на розвиток української музично-театральної культури II половини XIX - початку XX ст. Наведено приклади участі вітчизняних акторів у театральних постановках оперних творів діяча на українській і європейських сценах. Автором зазначено, що найбільш популярними стали опери «Галька», «Зачарований замок» («Страшний двір») i «Графиня». Виконання партій головних героїв із творів 
С. Монюшка сприяло всебічному розкриттю талантів таких відомих українських виконавців, як С. Крушельницька, О. Мишуга, Є. Зарницька, О. Петляш, М. Микиша, Т. Івлєв (Трохименко) та ін. Дослідницею детально висвітлено досвід постановки опер композитора в українському професійному театрі М. Садовського у Києві на початку XX ст. Всебічно проаналізовано досвід інсценізації п'єси «Галька» в перекладі українською мовою. Підкреслено, що п’єса відрізнялася чітко вираженою соціальною проблематикою, новаторством режисерських прийомів, а це робило твір доступнішим для масової аудиторії, однак автором констатовано, що вільна інтерпретація сюжету призвела до часткової невідповідності образно-музичного звучання засобам сценічної драматургії. У розвідці також простежено діяльність із постановки опер С. Монюшка як пересувними українськими трупами, так і театральними закладами, котрі діяли на українських землях протягом згаданого періоду.

\section{SUMMARY}

The study revealed the influence of the operatic heritage of the outstanding Polish composer S. Moniuszko on the development of Ukrainian musical and theatrical culture of the second half of the XIX - early $\mathrm{XX}$ centuries. It has been proved that Ukrainian actors have successfully participated in theatrical productions of the composer's operas on both the Ukrainian and European stages.

The operas "Halka", "The Haunted Manor" and "Countess" became the most popular. Performing parts of the main characters from the works of the composer contributed in the second half of the nineteenth century comprehensive disclosure of talents of such famous performers as S. Krushelnytska and O. Myshuga. The performances of the actors on the stage of the Warsaw Opera were highly praised by theatre critics. During his musical and theatrical activity, O. Myshuga performed more than 600 times in the role of Yontek from the opera "Halka".

It is shown that the creative heritage of S. Moniuszko significantly influenced the formation of the musical repertoire of groups operating in Western Ukraine. Thus, the composer's works were actively performed during chamber concerts in the mornings and evenings organized by the Galician Music Society, in the Sokol concert hall, etc.

The plays "Halka" and "The Haunted Manor" were also successful on the stage of the Kyiv Opera House. Prominent Russian composer, conductor and teacher P. Tchaikovsky after watching the opera "Halka" noted the excellent results of the sound of the choir. On the stage of this theatre for the first time in Russian was performed the opera "The Haunted Manor". 
M. Starytsky tried to stage the opera "Halka" with a translation of the libretto to the work in Ukrainian in 1887, but came across a ban on the manuscript of the play by the tsarist censorship.

The researcher highlights in detail the experience of performing operas by the composer in the Ukrainian professional theatre M. Sadovsky in Kiev in the early twentieth century. An interesting attempt to stage the play "Halka" in Ukrainian was the version of the work proposed by the director. The main events of the opera were moved to the Carpathian region, and Polish peasants were changed to Hutsuls. The innovative techniques of directing, the transfer of the folk character of the opera and the ethnographic color of the action, the vocal and dramatic talent of the performers were highly praised by critics. The play was characterized by clear social issues, psychological acuity and made the work more accessible to a mass audience.

However, the free interpretation of the plot led to a partial inconsistency of the figurative content of the music with the practice of its stage delivery. Giving the opera an artificially contrived Ukrainization contradicted S. Monyushko's creative idea, as well as violated the original musical sound of the work. This led to a figurative and stylistic change in the author's score.

During the period of the theater's activity, such well-known performers as V. Verkhovynets, O. Petlyash, M. Mykysha, T. Ivlev (Trokhimenko) and others took part in the staging of S. Monyushko's plays. The well-known Ukrainian musician and choral conductor O. Koshyts also addressed S. Monyushko's opera heritage. He successfully renewed the play "Halka" while working in the theatre group of M. Sadovsky.

The researcher revealed the experience of staging S. Monyushko's operas both by mobile Ukrainian troupes and theatrical establishments that operated on Ukrainian lands during this period. The author states that the opera "Halka" by S. Monyushko was also present in the repertoire of mobile Ukrainian troupes (O. Suslova, D. Haidamaki, etc.). During 1898-1909, the aria of Halka was performed by the famous Ukrainian actress and singer E. Zarnytska as part of the traveling theatre of O. Suslov. The work has also been repeatedly staged by director J. Stadnyk on the stage of the Western Ukrainian Theatre of the Ruska Besida society.

The opera "Halka" attracted attention at different stages of development of Ukrainian musical and theatrical culture. During the time of the Hetmanate of P. Skoropadsky, the libretto to the play was translated into Ukrainian. In 1919, the outstanding Ukrainian director L. Kurbas made significant efforts to stage a play in the State Ukrainian Musical Drama. However, the premiere of the play did not take place due to the entry of Denikin's troops into Kyiv.

The author of the study concludes that S. Monyushko's operas were successfully included in the repertoire of both mobile Ukrainian troupes and 
theatres that functioned in the Ukrainian lands in the second half of the XIX early XX centuries. The operas of the outstanding composer contributed to the formation of a whole galaxy of famous Ukrainian singers and dramatic actors.

\section{ЛІТЕРАТУРА}

1. Антонюк В. Олена Олександрівна Муравйова - професор вищої школи імені М.В. Лисенка. Микола Лисенко: історія і сучасність : збірник наукових праць. До 175-ої річниці від дня народження композитора / упоряд. Р. Скорульська, О. Гураль, ред. І. Чиркова. Київ, 2019. C. 4-23.

2. Безсмертна слава Соломії: біобібліографічний довідник / Муз.-мемор. музей С. Крушельницької у Львові; упоряд. : М. Зубеляк, Р. Мисько-Пасічник ; вступ. ст. І. Криворучки. Львів : Гердан Графіка, 2007. $242 \mathrm{c}$.

3. Бернацька-Гловаля Е. Польська пісня у Львові (соціоісторичний та культурологічний аспект). Наукові збірки Львівської національної музичної академії ім. М.В. Лисенка. 2013. Вип. 29. С. 151-166. URL: http://nbuv.gov.ua/UJRN/Nzlnma_2013_29_1.

4. Василенко Т.О. Діяльність хору Національного академічного театру опери та балету України ім. Т.Г. Шевченка в період другої половини XX - початку XXI століття: формування виконавської школи (інтертекстуальний аналіз) : автореф. дис. ... канд. мистецтвознавства : 26.00.01 ; Нац. муз. акад. України ім. П.І. Чайковського. Київ, 2016. $17 \mathrm{c}$.

5. Васильченко Т. Верховинець (Костів) Василь Миколайович. Реабілітовані історією. Полтавська область. Кн. 5 / упоряд. О.А. Білоусько. Київ - Полтава : Оріяна, 2007. С. 56-60.

6. Видатний співак Олександр Мишуга: спогади / зібрав І. Деркач. Львів : Каменяр, 1964. 119 с.

7. Врублевська В. Соломія Крушельницька : роман-біографія. Київ : Дніпро, 1986. 358 с. URL: https://itgazeta.com.ua/chytatyonlayn/vrublevska-valeria-vasilivna-solomia-krushelnicka/.

8. Гай-Нижник П. Становлення українського театрального мистецтва і питання його оподаткування за Гетьманату 1918 року. Украӥнський театр. 2003. № 5-6. С. 10-12.

9. Головащенко М. На вершині слави. Музика. 2003. № 3. С. 26-28.

10. Горський Г. Про оперу «Галька». URL: https://zbruc.eu/node/ 45366 (дата звернення: 22.01.2021).

11. Дем'янко Н.Ю. Формування національної культури молоді в педагогічній спадщині В.М. Верховинця. Полтава : АCMI, 2012. 270 с.

12. Історія українського театру : у 3 т. / НАН України, ІМФЕ ім. М.Т. Рильського ; редкол. : Г.А. Скрипник та ін. Київ, 2009. Т. 2: 1900-1945. / 
Л. Барабан, В. Гайдабура, О. Красильникова, Ю. Станішевський та ін. ; редкол. тому: І. Юдкін, О. Шевчук. 2009. 876 с.

13. Калениченко А. Монюшко Станіслав. Украӥнська музична енциклопедія. Київ : ІМФЕ, 2011. Т. 3. С. 482-483.

14. Kański J. Mistrzowie sceny operowej. Kraków : PWM, 1974. 442 s.

15. Кирик Л. Олександр Мишуга. Митщі Львівщини: календар ювіл. і пам'ят. дат на 1998 р. / уклад. : Н. Письменна, М. Кривенко. Львів, 1997. C. $48-52$.

16. Кінзерська Т. Єфросинія Зарницька (Є. Азгуріді): літопис життя і творчості (1867-1936). Київ : Інтерсервіс, 2019. 586 с.

17. Криль 3. Дань певцу из Виткова. Музыкальная жизнь. 1983. № 21. C. 5.

18. Леоненко Я., Фількевич Г. Музичний простір вистав Леся Курбаса. Нариси з історії театрального мистеитва Украӥни XX століття / Інститут проблем сучасного мистецтва Академії мистецтв України ; редкол.: В. Сидоренко та ін. Київ : Інтертехнологія, 2006. C. 325-350.

19. Мазепа Т.Л. Галицьке Музичне Товариство у культурномистецькому процесі XIX - початку XX століття : дис. ... докт. мистецтвознавства : 26.00.01 ; Національна академія керівних кадрів культури і мистецтв, Міністерство культури України. Київ, 2018. 568 с.

20. Олександр Мишуга: Спогади. Матеріали. Листи / упорядкув., підгот. текстів, вступ. ст. та прим. М. Головащенка. Київ, 1971. 779 с.

21. Романюк Л.Б. Діяльність польських музично-театральних товариств Станіславова на зламі XIX-XX століть. Наукові записки Тернопільського начіонального педагогічного університету імені Володимира Гнатюка. Серія : Мистеитвознавство. 2012. № 1. C. 27-34. URL: http://nbuv.gov.ua/UJRN/NZTNPUm_2012_1_7.

22. Садовський М.К. Мої театральні згадки: 1881-1917 рр. Харків, 1930. С. 90-91.

23. Самин Д. 100 великих композиторов. Москва : Вече, 2014. 432 с.

24. Солов'яненко А.А. Українська оперна режисура у контексті національної культури XIX - першої третини XX століття: генезис художніх форм. Часопис Національної музичної академї Украӥни імені П.I. Чайковського. 2013. № 1. С. 116-221. URL: http://nbuv.gov.ua/UJRN/Chasopys_2013_1_16/.

25. Станішевський Ю. Український театр кінця XIX - початку XX століть: Проблеми синтетичної природи i становлення національного режисерського мистецтва. Нариси 3 iсторії театрального мистецтва Украӥни XX століття / Інститут проблем сучасного мистецтва Академії мистецтв України ; редкол. : В. Сидоренко та ін. Київ : Інтертехнологія, 2006. С. 11-80. 
26. Stattler Ju. Z opery. Stowo (Варшава). 1898. № 230. S. 8-10.

27. Tomaszewski M. O muzyce polskiej w perspektywie intertekstualnej: Studia i szkice. Kraków : Akademia Muzyczna, 2005. 158 s.

28. Український драматичний театр: нариси історії : в 2 т. Т. 1. Дожовтневий період / АН УРСР, Ін-т мистецтвознавства, фольклору та етнографії ім. М.Т. Рильського ; відп. ред. М.Т. Рильський. Київ : Наук. думка, 1967. $518 \mathrm{c.}$

29. «Halka». Opera Stanisława Moniuszki. 100 lat na scenie. 18581958 / materiały zebrał i oprac. J. Grubowski. Warszawa : Państwowa opera w Warszawie, 1958. $112 \mathrm{~s}$.

30. Чайковский П.И. Киевская опера. Четвертое симфоническое собрание. Музыкально-критические статьи. Ленинград : Музыка, 1986. $365 \mathrm{c}$.

31. Чедрик В.Ю. Олександр Кошиць і його хор як вісник світової слави української пісні. Науковий часопис НПУ імені М.П. Драгоманова. Серія 14: Теорія і методика мистещької освіти. 2011. Вип. 11. С. 294-301. URL: http://nbuv.gov.ua/UJRN/ Nchnpu_014_2011_11_79.

32. Черепанин М.В. Мистецька палітра культурного життя Станиславова (Івано-Франківська): історичний контекст і музичний професіоналізм сьогодення. Науковий вісник Мукачівського державного університету. Серія: Педагогіка та психологія. 2018. Вип. 1. С. 68-72. URL: http://nbuv.gov.ua/UJRN/nvmdupp_2018_1_17. DOI: $10.31339 / 2413-3329-2018-1(7)-68-72$

33. Щепакін В. Польсько-українські музичні зв'язки. Українська музична енциклопедія. Т.5. Київ : Видавництво ІМФЕ, 2018. С. 345-357.

34. Щурик Б. Про інтерпретацію вокальних творів Соломією Крушельницькою. Молодь і ринок. 2013. № 4. С. 129-132. URL: http://nbuv.gov.ua/UJRN/Mir_2013_4_27.

\section{Information about the author:} Fedotova O. O.,

Doctor of Historical Sciences, Senior Research Officer, Professor at the Department of Public Administration and Law Kyiv University of Culture 20, Chigorin str., Kyiv, Ukraine 